\title{
SUMMARY REPORT: HYDROGEN GENERATION IN SRAT WITH NITRIC ACID AND LATE WASHING FLOWSHEETS
}

\author{
by C.W. Hsu
}

Westinghouse Savannah River Company

WSRC-RP-92-1236

Savannah River Site

Aiken, South Carolina 29808

DE93 006882

Other Authors:

\section{DISCLAIMER}

\begin{abstract}
This report was prepared as an account of work sponsored by an agency of the United States Government. Neither the United States Government nor any agency thereof, nor any of their employees, makes any warranty, express or implied, or assumes any legal liability or responsibility for the accuracy, completeness, or usefulness of any information, apparatus, product, or process disclosed, or represents that its use would not infringe privately owned rights. Reference herein to any specific commercial product, process, or service by trade name, trademark, manufacturer, or otherwise does not necessarily constitute or imply its endorsement, recommendation, or favoring by the United States Government or any agency thereof. The views and opinions of authors expressed herein do not necessarily state or reflect those of the United States Government or any agency thereof.
\end{abstract}

This paper was prepared in connection with work done under Contract No. DE-AC09-89SR18035 with the U. S. Department of Energy. By acceptance of this paper, the publisher and/or recipient acknowledges the U.S. Government's right to retain a nonexclusive, royalty-free license in and to any copyright covering this paper, along with the right to reproduce and to authorize others to reproduce all or part of the copyrighted paper. 


\section{DISCLAIMER}

This report was prepared as an account of work sponsored by an agency of the United States Government. Neither the United States Government nor any agency thereof, nor any of their employees, makes any warranty, express or implied, or assumes any legal liability or responsibility for the accuracy, completeness, or usefulness of any information, apparatus, product, or process disclosed, or represents that its use would not infringe privately owned rights. Reference herein to any specific commercial product, process, or service by trade name, trademark, manufacturer, or otherwise does not necessarily constitute or imply its endorsement, recommendation, or favoring by the United States Government or any agency thereof. The views and opinions of authors expressed herein do not necessarily state or reflect those of the United States Government or any agency thereof.

This report has been reproduced directly from the best available copy.

Available to DOE and DOE contractors from the Office of Scientific and Technical Information, P. O. Box 62, Oak Ridge, TN 37831; prices available from (615) 576-8401.

Available to the public from the National Technical Information Service, $U$. $S$. Department of Commerce, 5285 Port Royal Rd., Springfield, VA 22161. 
Keywords :

DWPF, SRAT, Formic Acid, Nitric Acid Flowsheet, Noble Metals, Catalysis, Hydrogen

Retention Period: Permanent

CC: L. M. Poapouchado, 773-A

L. F. Landon, 704-T

J. T. Carter, 704-1T

M. J. Plodinec, 773-A

C. T. Randal1, 704-T

J. R. Zamecnik, 704-1T

J. A. Ritter, 704-1T

N. E. Bibler, 773-A

D. M. Ferrara, 773-A

B. C. Ha, 773-A.

SRTC Records (4)

October 22,1992

TO: E. W. HOLTZSCHEITER, 773-A

FROM: C. W. HSU, $\mathrm{CINH}$

SUMMARY REPORT: HYDROGEN GENERATION IN SRAT WITH NITRIC ACID AND LATE WASHING FIOWSHEETS (U)

\section{SUMMARY}

Melter feed preparation processes, incorporating a final wash of the precipitate slurry feed to DWPF and a partial substitution of the SRAT formic acid requirement with nitric acid, should not produce peak hydrogen generation rates during cold Chemical Runs (CCR's) and radioactive operation greater than their current, respective hydrogen design bases of $0.024 \mathrm{lb} / \mathrm{hr}$ and $1.5 \mathrm{lb} / \mathrm{hr}$. A single SRAT bench-scale process simulation for CCR's produced a DWPF equivalent peak hydrogen generation rate of $0.004 \mathrm{lb} / \mathrm{hr}$. During radioactive operation, the peak hydrogen generation rate will be dependent on the extent DWPF deviates from the nominal precipitate hydrolysis and melter feed preparation process operating parameters.

Two actual radioactive sludges were treated according to the new flowsheets. The peak hydrogen evolution rates were equivalent to 0.038 and $0.20 \mathrm{lb} / \mathrm{hr}$ (DWPF scale) respectively. Compared to the formic acid - HAN hydrolysis flowsheets, these peak rates were reduced by a factor of 2.5 and 3.4 for Tank 15 and Tank 11 sludges, respectively.

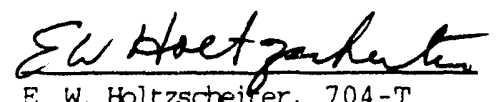

E. W. Holtzscheiler, 704-T

Authorized Derivative Classifier 
The bench-scale .. "oping studies showed that with the new PHA simulant, the : llowing factors affect the hydrogen generation rate: amount of acid, the presence of high mercury content ( $3.5 \mathrm{wt} \%)$, the PHA evaporation rate and the source of PHA.

Two IDMS demonstration runs using the new flowsheets were conducted. The peak hydrogen generation rate obtained from IDMS PX5 and IDMS PX4 were 0.67 and $0.21 \mathrm{lb} / \mathrm{hr}$ respectively (DWPF scale). These levels corresponded to 55 and $86 \%$ decreases in the peak hydrogen generation rate compared to the design basis from the HAN and formic acid flowsheets. IDMS PX4 was conducted under conditions close to the nominal operating conditions with the exception of the slower PHA evaporation rate. PX5 was operated with the deviations specified by the DWPF Technical. However, during PX5 numerous IDMS process interlocks interrupted the run when the hydrogen first began to increase rapidly. The peak hydrogen generation rate was delayed by up to seven hours, thus the observed rate may be lower than that of an uninterrupted run. However, it is not expected to exceed the $1.5 \mathrm{lb} / \mathrm{hr}$ (DWPF scale design basis) according to the bench-scale scoping study of the impact of cycle time on the peak hydrogen generation rate.

\section{INTRODUCTION}

Recently, SRTC recommended two process changes: 1) a final wash ' $f$ the tetraphenylborate precipitate feed slurry and 2) the use of nitric acid to neutralize the sludge in the SRAT. The first change produced an aqueous hydrolysis product (PHA) with higher formic acid/formate and copper concentration, and reduced the nitrate content in the PHA by an order of magnitude. The second change is to substitute part of formic acid added to the SRAT with nitric acid, and therefore may reduce the hydrogen generated in the SRAT as well as provide nitrate as an oxidant to balance the redox state of the melter feed.

Since the discovery that hydrogen would be produced during sludge treatment in the DWPF, a design basis for a controlled forced air purge and on-line hydrogen monitor system was developed and provided to DWPF for safe operation. Three major efforts were initiated to investigate methods to reduce the peak hydrogen evolution rate to a level substantially below that which had been recommended in the original DWPF formic acid hydrolysis flowsheet:

- Bench-scale scoping experiments (2 L sludge/batch) using nonradioactive sludge simulant to investigate the pertinent process variables and conditions that could affect the hydrogen generation rates. 
- Bench-scale tests (0.1 L sludge/batch) using actual radioactive HLW sludge in the shielded cells to validate results of tests using simulants.

- One-fifth DWPF scale runs (1100 gallons) using simulants to demonstrate the process.

The details of the work from the three areas are documented in detail indivicually in WSRC-RP-92-1194, WSRC-RP-92-1137, WSRC-RP-92-1213, and WSRC-RP-92-1237,1,2,3,4

\section{RESULTS AND DISCUSSION}

Bench-scale scoping study with sludge simulant

a. cold Chemical Run Simulation

A SRAT ber.ch-scale process simulation was carried out with aqueous product (PHA) produced during hydrolysis at the revised process operating parameters and using nitric acid to neutralize the sludge simulant. Results indiated that with a low-nitrite purex sludge that did not contain mercury or noble metals, the hydrogen generation rate would be equivalent of $0.004 \mathrm{lb} / \mathrm{hr}$ (DWPF scale). This rate is far below the original basis $(0.024 \mathrm{lb} / \mathrm{hr})$ used to design the controlled air purge system for flammability control during CCR's.

b. Sludge Simulant Containing Noble Metals

A series of bench-scale scoping experiments were conducted using sludge simulants containing the full complement of the noble metals at the highest projected level $(0.044$ wt $\%$ Rh, 0.094 wt: Pd ard 0.219 wt\% Ru based on the sludge solids). The results are summarized in Table $I$. With the new PHA from late-wash hydrolysis simulant added to the sludge at the maximum volume ratio( $2: 1.1)$, and the amount of acid added similar to the nominal amount, the peak hydrogen generation rate was $0.55 \mathrm{lb} / \mathrm{hr}$ DWPF scale. Other findings are described below.

- A longer induction period, a reduction of the peak hydrogen generation rate, and a more gradual rise in the hydrogen evolution resulted compared to those observed with the original formic acid flowsheet.

- The presence of mercury increased the hydrogen generation rate by a factor of 7 . The effect of mercury seemed to be highly related to the new PHA simulant from the latewashing hydrolysis.

- The hydrogen generation rate is affected by the amount of nitric acid added. 


\section{SAVANNAH RIVER TECHNOLOGY CENTER}

- The source of PHA affects the hydrogen generation rate. When PHA from the washed irradiated precipitate slurry was used, the hydrogen generation rate was only one third of the rate obtained when an unirradiated precipitate slurry was used.

- A reductior of PHA addition/evaporation rate by a factor of four reduced the peak hydrogen generation rate by a factor of 2.5 .

\section{Validation Experiments with Actual Radioactive Sludges}

The hydrogen generation rates during radioactive sludge processing in the SRAT were compared for the proposed nitric acid-late wash flowsheet and the original formic acid-HAN flowsheet. When nitric acid and PHA produced in PHEF according to the late-washing flowsheet was used, the peak hydrogen evolution rates were equivalent to 0.038 and $0.20 \mathrm{lb} / \mathrm{hr}$ (DWPF scale) respectively. Compared to the formic acid - HAN hydrolysis flowsheets, these peak rates were reduced by a factor of 2.5 and 3.4 for Tank 15 and Tank 11 sludges, respectively.

Tank 15 sludge $v^{\prime i l l}$ be the most active hydrogen-generating sludge to be blended for Batch 1 DWPF radioactive operation. Therefore hydrogen generated by processing Tank 15 sludge can be treated as a worst case scenario for the first sludge batch. Tank 11 sludge contains the most active catalysts for hydrogen generation when tested with formic acid treatment of sludge. The peak hydrogen evolution rate with nitric acid flowsheet is well below the DWPF design basis of $1.51 \mathrm{~b} / \mathrm{hr}$.

\section{IDMS Process Demonstration}

The design basis peak hydrogen generation rate from the HAN and formic acid flowsheets was $1.5 \mathrm{lb} / \mathrm{hr}$ (DWPF scale). This number was based on an IDMS run (PX2) operated with $25 \%$ excess formic acid, which was considered to be a credible deviation from nominal operating conditions. Moreover, for the HAN and Formic Acid Flowsheets, excess formic acid was the only creditile deviation which could markedly impact the generation of hydrogen. This was not the case for the Late Washing and Nitric Acid Flowsheets, however.

For the late washing and nitric acid flowsheets there are many deviations from the operating conditions which can adversely impact the hydrogen generation rate. These deviations, as specified by DWPF Technical, from the nominal and/or maximum operating conditions were included in IDMS PX5. In contrast, IDMS PX4 was performed under conditions much closer to the nominal operating conditions with the exception of the PHA evaporation rate. 


\section{SAVANNAH RIVER TECHNOLOGY CENTER}

The peak hydrogen generation rate obtained from IDMS PX5 and IDMS PX4 were respectively 0.67 and $0.21 \mathrm{lb} / \mathrm{hr}$ (DWPF scale). These levels corresponed to 55\% and 86\% decreases in the peak hydrogen generation rate compared to the design basis obtained from the HAN and formic acid flowsheets. During PX5 numerous IDMS process interlocks interrupted the run when the hydrogen first began to increase rapidly. The peak hydrogen generation rate was delayed by up to seven hours, thus the observed rate may be lower than that of an uninterrupted run. However, it is not expected to exceed the $1.5 \mathrm{lb} / \mathrm{hr}$ (DWPF scale design basis) according to the bench-scale scoping study of the impact of cycle time on the peak hydrogen generation rate.

\section{REFERENCES}

1. C. W.Hsu, "Validation Of Hydrogen Design Basis For DWPF Cold Chemical Runs With Nitric Acid And Late Washing Flowsheets", WSRCRP-92-1194 (1992).

2. C. W. Hsu, "Hydrogen Generation In SRAT With Nitric Acid And Late Washing Flowsheets", WSRC-RP-1213 (1992)

3. D. M. Ferrara, N. E. Bibler, and B. C. Ha, "Hydrogen Production During Processing of Radioactive Sludge Using Conditions of The Nitric Acid-Late Wash Flowsheet", WSRCRP-92-1137 (1992).

4. J. A. Ritter, "Hydrogen Generation During IDMS Demonstrations of The Late Washing And Nitric Acid Flowsheets", WSRC-RP-92-1237 (1992). 


\section{TABLE 1. SUMMARY OF BENCH-SCALB SCOPING EXPERIMENTS}

Effect of $\mathrm{HNO}_{3}$ Addition

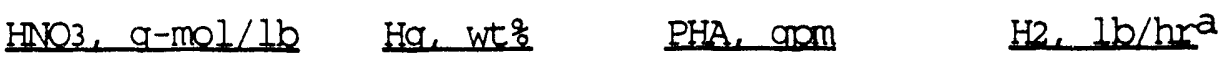
1.06
0
$12-14$
0.23
0.70
0
$12-14$
0.08
0.45
$12-14$
0.04

Effect of tha content of sludge

HNO3, $a-m o l / l b$

0.70

0.70
Ha, wt

0

3.5
PHA. GOM

$12-14$

$12-14$
H2. $1 \mathrm{~b} / \mathrm{hr}^{\mathrm{a}}$

0.08

0.55

\section{Effect of PHA Addition Rate}

HNO3, g-mol/1b

0.70

0.70
$\mathrm{Hg}, \mathrm{wt} \frac{\mathrm{O}}{\mathrm{s}}$

3.5

3.5
PHA, GOM

$12-14$

2.6
$\mathrm{H}_{2}, \mathrm{lb} / \mathrm{hra}^{\mathrm{a}}$

0.55

0.20

\section{Effect of source of PHA}

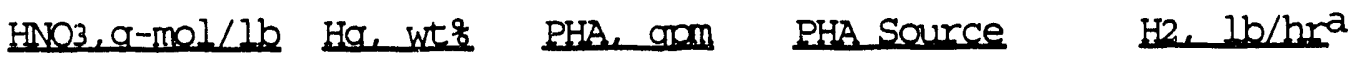

$\begin{array}{lllll}0.70 & 3.5 & 12-14 & \text { Unirradiated } & 0.55 \\ 0.70 & 3.5 & 12-14 & \text { IrradiatedC } & 0.17\end{array}$

a. DWPF scale, 19 wo sludge solids

b. Unirradiated Late wash PHA acid in PHA $0.24 \mathrm{M}$

formate in PHA $23,400 \mathrm{mg} / \mathrm{L}$

c. Irradiated Late wash PHA

acid in PHA $0.24 \mathrm{M}$

formate in PHA $18,700 \mathrm{mg} / \mathrm{L}$ 

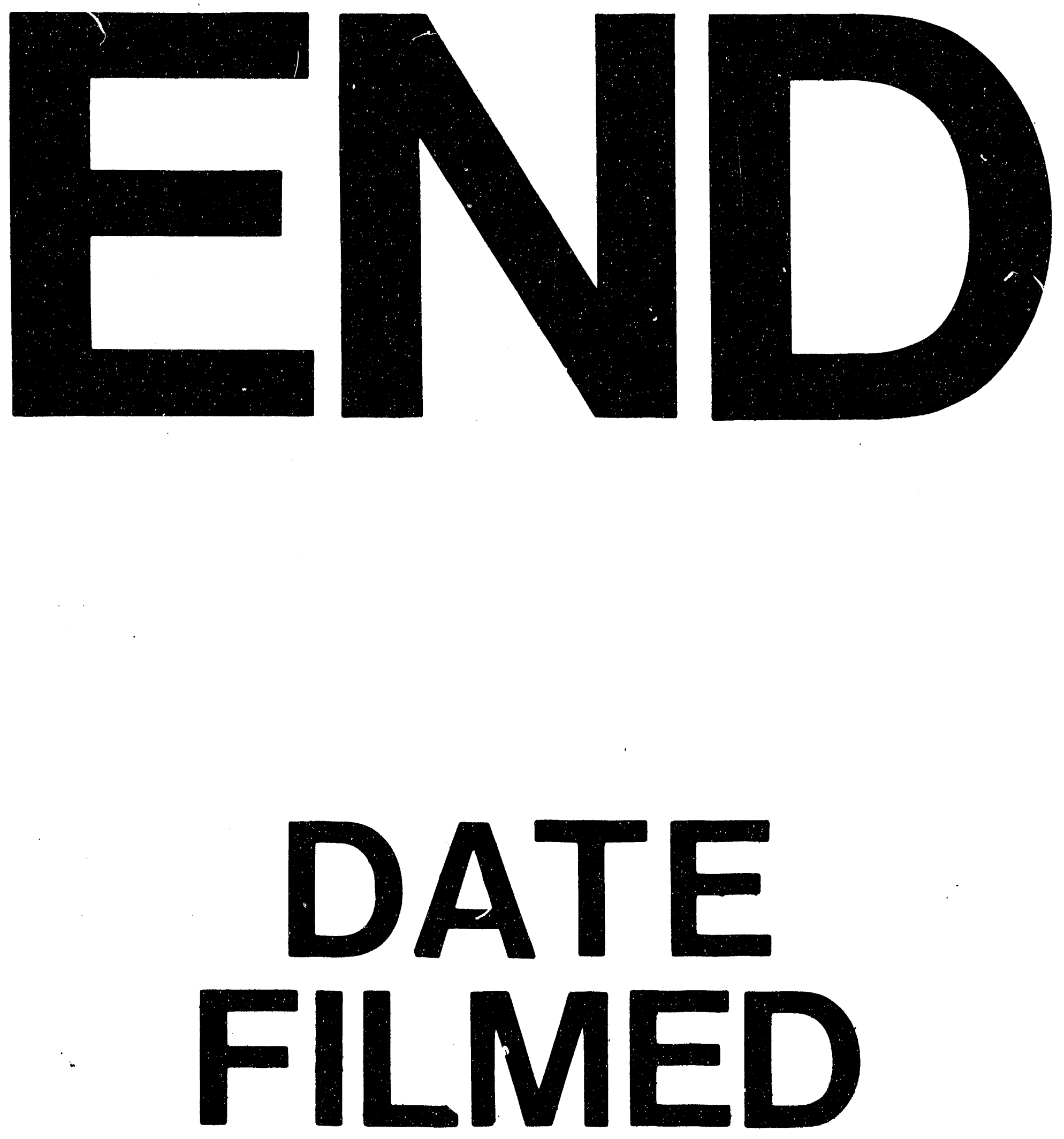

1

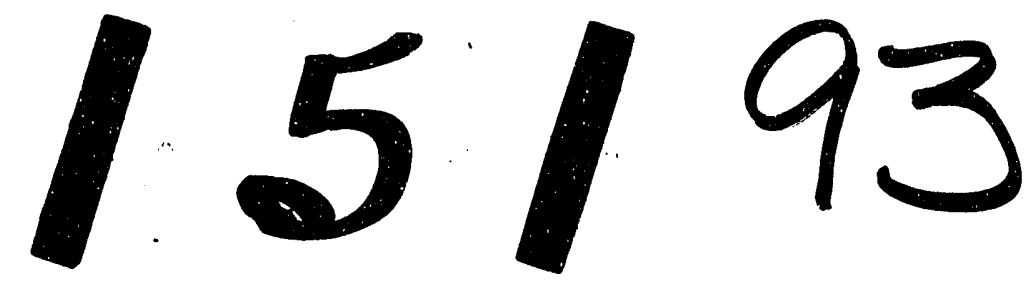


